\title{
Reforms and sanitary covid crisis: have spatial inequalities in resuscitation beds increased since $2008 ?$
}

Réformes hospitalières et crise pandémique de la Covid-19: depuis 2008 les inégalités spatiales d'équipement en lits de réanimation ont-elles augmenté?

Benoit Conti, Sophie Baudet-Michel and Charlène Le Neindre

\section{(2) OpenEdition} Journals

Electronic version

URL: http://journals.openedition.org/rfst/941

DOI: $10.4000 /$ rfst.941

ISSN: 2492-3672

\section{Publisher}

Espaces et SOciétés (UMR 6590)

\section{Electronic reference}

Benoit Conti, Sophie Baudet-Michel and Charlène Le Neindre, "Reforms and sanitary covid crisis: have spatial inequalities in resuscitation beds increased since 2008?", Revue francophone sur la santé et les territoires [Online], Pandemic, crises and perspectives: territorial readings of Covid-19, Online since 12 March 2021, connection on 06 April 2021. URL: http://journals.openedition.org/rfst/941 ; DOI: https:// doi.org/10.4000/rfst.941

This text was automatically generated on 6 April 2021.

\section{(i) (2)

La Revue francophone sur la santé et les territoires est mise à disposition selon les termes de la Licence Creative Commons Attribution - Pas d'Utilisation Commerciale - Partage dans les Mêmes Conditions 4.0 International. 


\title{
Reforms and sanitary covid crisis: have spatial inequalities in resuscitation beds increased since $2008 ?$
}

\author{
Réformes hospitalières et crise pandémique de la Covid-19: depuis 2008 les \\ inégalités spatiales d'équipement en lits de réanimation ont-elles augmenté?
}

Benoit Conti, Sophie Baudet-Michel and Charlène Le Neindre

1 Since 2000, bed short-stay hospitalization closures have continued in almost all urban areas, with around sixty of them disappearing altogether. The decrease in the number of short-stay beds is well known. Less well known is the way in which hospital reforms have altered hospital capacities in resuscitation unit.

2 This paper analyses the evolution of the geography of the resuscitation bed equipment, particularly at stake during the COVID-19 epidemic in France. Analysis are conducted at the functional urban areas and regional levels, and in two situations: reforms in the last 10 years and 2020 sanitary crisis. Data is provided by the Annual Statistics of Healthcare Institutions, which provides information, relative to resuscitation, intensive care and continuous monitoring beds over the period 2008-2018. Using this database, measures in volume and density of equipment allows us to analyse the evolution of the spatial structure of resuscitation equipment in France. How has the distribution of resuscitation equipment evolved over the last decade? Have resuscitation beds been closed and if so, where?

3 Since 2008, numbers in resuscitation beds in metropolitan France remain virtually stable, rising from 4,983 to 4,923 beds. Resuscitation beds are highly polarised throughout the country, involving 150 functional urban areas. Although only 60 beds were closed at national level, this figure conceals opposite local changes. Density of resuscitation beds has decreased over the period: the average level of density in the sample of equipped urban areas decreased from 14.5 to 13.1 beds per 100,000 
inhabitants. The bed density indicator reveals that twice as many urban areas are in fact affected by a decrease in the number of resuscitation bed facilities. At the regional level, a linear regression between the initial density of beds in 2008 and the rate of variation in the number of beds over the period (2008-2018) shows inter-regional convergence: regions with the highest resuscitation beds densities in 2008 show most negative variation rates in bed numbers; conversely, regions least equipped in 2008 mostly show positive or slightly negative variation rates.

In the sanitary crisis situation, the potential of transformation, based on the capacity to convert intensive care and monitoring beds into resuscitation beds, is $240 \%$ at national level. This theoretical transformation potential would increase the volume of existing resuscitation beds by a factor of 3.4, i.e. from 4,923 resuscitation beds to 16,751 . At local level, this potential varies greatly (standard deviation of $117 \%$ ), from $33 \%$ in Digne-lesBains, or 55\% in Thonon-les-Bains to 706\% in Avignon or 683\% in Limoges. Large urban areas stand out with average transformation potential. At regional level, the average transformation potential is $284 \%$. Inter-regional differences are smaller than between urban areas: 21 of the 22 regions have a transformation potential between 2.8 and 4.5 times the number of resuscitation beds.

In conclusion, these results raise the more general question of the ability of hospitals to cope with epidemic crises, which are unfortunately not new. If patient transfers have helped to contain the tension in the resuscitation units of the highly affected regions in the spring of 2020, what is the situation in the autumn of 2020 , or winter and spring 2021 in a context where all the regions are affected? It appears that hospital medical staff have learned from the first epidemic wave and are now reorganising when patients' inflows increase drastically under "Plan Blanc" in order to cope with the increase. This means that medical staff from specialised departments (such as internal medicine for example) are temporarily moved from their current departments to COVID and reanimation departments. Therefore, hospitals which were already under pressure from the productive hospital reforms implemented in the first two decades of the 2000s, have been under threat of collapse since the beginning of the pandemic. However, the tensions brought to light by the pandemic has not led public authorities to question the productivity strategies implemented for more than 20 years under the NPM ideology: closures of MCO hospitals beds has been pursued in 2020 . 


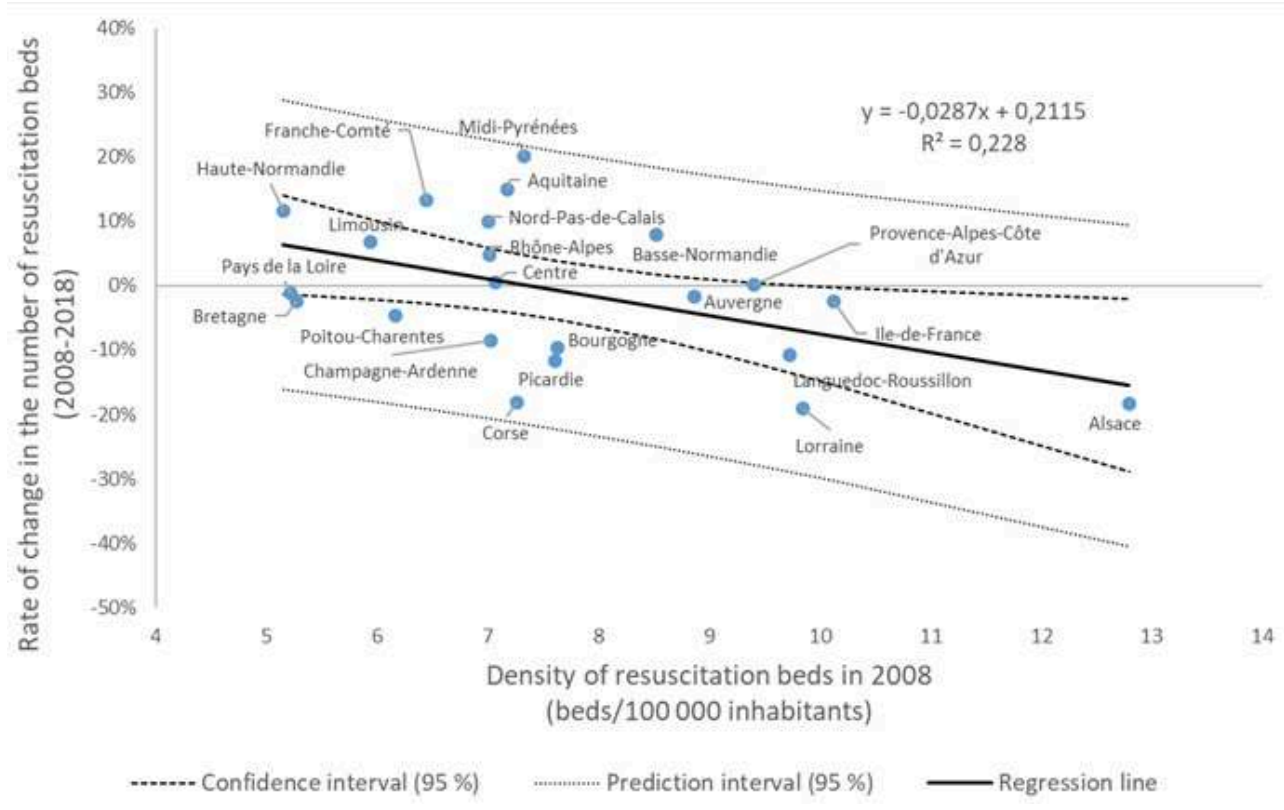

INDEX

Keywords: Covid-19, intensive care beds, hospitals, regions, urban areas

\section{AUTHORS}

BENOIT CONTI

LVMT, Université Gustave Eiffel, Ecole des Ponts, Champs-sur-Marne, France,

\section{SOPHIE BAUDET-MICHEL}

UMR Géographie-cités, Université de Paris

\section{CHARLÈNE LE NEINDRE}

IRDES 